\title{
METABOLIC PROFILE IN BEEF BULLS UNDER CONDITIONS OF INDUSTRIAL TECHNOLOGIES
}

\author{
P. JAGOŠ, J. ILLEK, J. DOUBEK and JANA JURAJDOVÁ \\ Department of Diagnosis, Therapy and Control of Animal Diseases, \\ University of Veterinary Science, 61242 Brno
}

Received December 12, 1983

\begin{abstract}
Jagoš, P., Illek, J., Doubek, J., Jurajdová, Jana.: Metabolic Profile in Beef Bulls under Conditions of Industrial Technologies. Acta vet. Brno, 54, 1985: 41-51.

The development of health condition of animals was followed in 10 specializer establishments of cattle fattening using the system of preventive diagnoses. The metabolic profile of healthy bulls and those suffering from disorders of the type of metabolic acidosis, alkalosis, rachitis, hyperphosphataemia and hypomagnesaemia was determined. Statistically significant differences of basic biochemical data between the group of healthy animals and those affected with individual metabolic disorders were found. The causes and the character of changes in the biochemical profile of individual animal groups and the possibilities of the application of new findings in an early diagnosis of metabolic disorders in beef bulls are discussed.
\end{abstract}

Cattle fattening, metabolic acidosis, metabolic alkalosis, hyperphosphataemia, rachitis, hypomagnesaemia.

The purpose of the intensive animal breeding is to increase the production of beef cattle. This goal is being achieved both by better utilization of potential growth capacity of our breeds and their crosses with beef types and by decreasing the losses caused by the lowered nutrient conversion, diseases and emergency slaughter of animals. The preferential task in solving of these problems has been attributed to the nutrition of animals reared under these technologies which is a limiting factor not only for the growth intensity but also for the morbidity and the resulting losses.

New knowledge in the field of animal nutrition and the rapid development of clinical biochemistry create favourable conditions for the investigation and influencing the growth capacity of young cattle, for its active production and health control. The main aim of these efforts has been to ensure optimal, economically effective production of wholesome and safe foodstuffs of high nutritional value for human consumption.

The examination of biological fluids and tissues using modern laboratory techniques has already been commonly used in diagnosis of production and metabolic disorders in dairy cows and calves not only abroad (Payne 1977) but also in this country (Jagoš et al. 1975, 1977, 1980). Lately, a system of preventive diagnosis for breeding of sheep and sows has also been worked out (Jagoš et al. 1980, 1981). Till now, no detailed findings have been published concerning hematological and biochemical parameters in healthy bulls compared with those suffering from metabolic disorders.

\section{Material and Methods}

The experiment was carried out in 10 bull fattening centres with the capacity of $400-1000$ animals with modern management and housing in the duration of three years. Free housing with slatted floor and deep litter have been used in 7 and 3 high-capacity calf houses, resp. The basic feed ration consisted of maize silage $(12-20 \mathrm{~kg} / \mathrm{animal}$ and day) and of pressed feeds containing concentrates and urea. In six fattening centres this feed ration was supplemented by poultry litter.

The group screening of animals and preliminary evaluation of housing technology was carried out in each breed. The feed ration, the average body mass gain, the consumption of concentrates per $\mathrm{kg}$ of gain and the losses caused by emergency slaughter and death were found. 
From each fattening house a group of $10-25$ bulls of the Bohemian Spotted breed, with body mass of $320-400 \mathrm{~kg}$, and without clinical signs of illness was selected twice a year. In individual animals basic clinical examination, blood and bone tissue sampling were conducted. Altogether 631 bulls were examined during 3 years.

Blood samples for the determination of hematological and biochemical parameters were taken from v. jugularis. Bone biopsy of tuber coxae was used to obtain bone tissue samples.

In order to determine the acid-base status the blood samples were taken anaerobically into heparinized syringes and then kept in an icy water bath prior to analysis. Blood samples for biochemical examination were collected into heparinized tubes, centrifuged within 30 minutes of sampling and the plasma was immediately separated from erythrocytes.

Blood samples for hematological examination were taken into tubes containing anticoagulant.

Hemoglobin and hematocrit values were determined on the Coulter Counter instrument. Methemoglobin was measured photometrically by the method according to Homolka (1971).

The acid-base balance of the venous blood was found using the equilibration method on the Astrup instrument BME 22 (Radiometer). The Siggaard-Andersen nomogram (Sigaard-Andersen 1963) was used.

The total protein of the blood plasma and the levels of inorganic phosphorus and urea were determined photometrically using the Bio-test (Lachema). The glucose content in blood plasma was found by a specific enzymatic method using the Beckman glucose analyzer. The concentrations of $\mathrm{Na}, \mathrm{K}, \mathrm{Ca}, \mathrm{Mg}, \mathrm{P}, \mathrm{Zn}$ and $\mathrm{Cu}$ in the blood plasma were determined by the atomic absorption spectrophotometry on the Hilger Atomspek. The standard solutions for the AAS (Harleco) and the control sera of Hyland were used for calibration.

The collected samples of the cancellous bone tissue were made up to constant volume of the fresh tissue. Fat was extracted from the bone tissue by ether using the Soxhlet instrument. The samples were dried at $105^{\circ} \mathrm{C}$ for 48 hours, then weighed and mineralized by heating in a muffle furnace at $550^{\circ} \mathrm{C}$.

From the total number of 631 investigated bulls both healthy animals and those with metabolic disturbances were selected on the basis of clinical and clinico-biochemical examinations. In animals with subclinical disturbances the values of basic hematological parameters in blood and blood plasma were determined. The significance of differences in biochemical values of healthy bulls and those with metabolic disturbances has also been evaluated.

The results obtained were processed on the Model 9810 A minicomputer. The arithmetic mean $\overline{(\mathbf{x})}$ and the standard deviation (s) for the group of healthy animals and that of animals with individual metabolic disturbances were computed. The Student's t-test and critical values of the Student's t-distribution of frequencies (Myslivec 1957) were used for the testing of the difference significance of two means.

\section{Results}

The reference values of the basic hematological and biochemical parameters (Table 1) were obtained from bulls without clinical sigrs of a disease, with a good growth rate and with an optimal level of nutrition. The set comprised 144 bulls with average daily gains from 0.80 to $1.24 \mathrm{~kg}$.

Hematological and biochemical parameters of blocd and blood plasma of bulls with subclinical metabolic acidosis are presented in Table 2, those found in bulls with subclinical metabclic alkalosis in Table 3. Table 4 and Table 5 give the concentrations in bulls with rachitis and hyperphosphataemia, resp. Data concerning animals with hypomagnesaemia are presented in Table 6 . The statistical significance of differences of values of selected hematological and biochemical parameters between healthy animals and those with metabolic disturbances is shown in Table 7. In bulls with metabolic acidosis significant changes in acid-base status, urea and phosphorus in the blood plasma were observed. In bulls with metabolic alkalosis a significantly higher value of $\mathrm{BE}, \mathrm{SB}$, inorganic phosphorus and zinc and significantly lower values of hematocrit and magnesium have been found. Significant differences in the values of acid-base status of blood, in potassium and zinc of blood plasma have also been determined in bulls with subclinical rachitis. In hyperphosphataemic bulls significant differences in acid-base status, hematocrit, total protein, urea, inorganic 
Table 1

Reference values of basic biochemical parameters in blood and blood plasma of healthy bulls

\begin{tabular}{|c|c|c|c|}
\hline Parameter & Unit & $\bar{x}$ & $\mathbf{s}$ \\
\hline $\begin{array}{l}\text { Blood pH } \\
\text { pCO } \\
\text { BE } \\
\text { SB } \\
\text { BB } \\
\text { Hematocrit } \\
\text { Hb } \\
\text { Total protein } \\
\text { Glucose } \\
\text { Urea } \\
\text { Na } \\
\text { K } \\
\text { Ca } \\
\text { Mg } \\
\text { P } \\
\text { Zn } \\
\text { Cu }\end{array}$ & $\begin{array}{l}\mathrm{kPa} \\
\mathrm{mmol} / 1 \\
\mathrm{mmol} / \mathrm{l} \\
\mathrm{mmol} / 1 \\
\mathrm{~g} / \mathrm{dl} \\
\mathrm{g} / \mathrm{l} \\
\mathrm{mmol} / 1 \\
\mathrm{mmol} / 1 \\
\mathrm{mmol} / 1 \\
\mathrm{mmol} / 1 \\
\mathrm{mmol} / 1 \\
\mathrm{mmol} / 1 \\
\mathrm{mmol} / 1 \\
\mu \mathrm{mol} / 1 \\
\mu \mathrm{mol} / 1\end{array}$ & $\begin{array}{r}7.411 \\
5.766 \\
1.657 \\
25.277 \\
50.822 \\
0.359 \\
12.207 \\
70.044 \\
4.451 \\
5.058 \\
144.243 \\
5.135 \\
2.561 \\
0.981 \\
2.525 \\
22.485 \\
16.807\end{array}$ & $\begin{array}{l}0.019 \\
0.467 \\
1.421 \\
1.316 \\
4.035 \\
0.059 \\
1.786 \\
9.440 \\
0.750 \\
1.029 \\
4.171 \\
0.485 \\
0.217 \\
0.105 \\
0.269 \\
4.953 \\
3.149\end{array}$ \\
\hline
\end{tabular}

Table 2

Basic biochemical values of blood and blood plasma of bulls with metabolic acidosis

\begin{tabular}{|c|c|c|c|}
\hline Parameter & Unit & $\bar{x}$ & $\mathbf{s}$ \\
\hline $\begin{array}{l}\text { Blood pH } \\
\text { pCO }_{2} \\
\mathrm{BE} \\
\text { SB } \\
\text { BB } \\
\text { Hematocrit } \\
\text { Hb } \\
\text { Total protein } \\
\text { Glucose } \\
\text { Urea } \\
\text { Na } \\
\text { K } \\
\mathrm{Ca} \\
\mathrm{Mg} \\
\mathrm{P} \\
\mathrm{Zn} \\
\mathrm{Cu}\end{array}$ & $\begin{array}{l}\mathrm{kPa} \\
\mathrm{mmol} / 1 \\
\mathrm{mmol} / 1 \\
\mathrm{mmol} / 1\end{array}$ & $\begin{array}{r}7.342 \\
5.491 \\
-3.488 \\
20.965 \\
46.295 \\
0.358 \\
12.379 \\
70.625 \\
4.270 \\
6.133 \\
144.128 \\
5.049 \\
2.583 \\
0.995 \\
2.688 \\
23.997 \\
16.825\end{array}$ & $\begin{array}{l}0.034 \\
0.563 \\
2.334 \\
1.881 \\
4.824 \\
0.074 \\
1.453 \\
8.586 \\
0.817 \\
1.215 \\
4.636 \\
0.519 \\
0.214 \\
0.136 \\
0.392 \\
8.812 \\
3.687\end{array}$ \\
\hline
\end{tabular}

Table 3

Basic biochemical values of blood and blocd plasma in bulls with metabolic alkalosis

\begin{tabular}{|c|c|c|c|}
\hline Parameter & Unit & $\bar{x}$ & $\mathbf{s}$ \\
\hline $\begin{array}{l}\text { Blood pH } \\
\text { pCO } \\
\text { BE } \\
\text { SB } \\
\text { BB } \\
\text { Hematocrit } \\
\text { Hb } \\
\text { Total protein } \\
\text { Glucose } \\
\text { Urea } \\
\text { Na } \\
\text { K } \\
\mathrm{Ca} \\
\mathrm{Mg} \\
\mathbf{P} \\
\mathrm{Zn} \\
\mathrm{Cu}\end{array}$ & 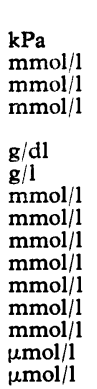 & $\begin{array}{r}7.428 \\
6.215 \\
5.477 \\
28.646 \\
53.215 \\
0.276 \\
11.083 \\
65.469 \\
4.731 \\
5.821 \\
147.583 \\
4.746 \\
2.551 \\
0.881 \\
2.837 \\
30.035 \\
16.586\end{array}$ & $\begin{array}{r}0.024 \\
0.645 \\
0.692 \\
0.585 \\
2.114 \\
0.098 \\
0.989 \\
10.227 \\
0.729 \\
1.185 \\
4.295 \\
0.397 \\
0.170 \\
0.105 \\
0.410 \\
11.403 \\
4.300\end{array}$ \\
\hline
\end{tabular}


Table 4

Basic biochemical values of blood and blood plasma in bulls with rachitis

\begin{tabular}{|c|c|c|c|}
\hline Parameter & Unit & $\bar{x}$ & $\mathbf{s}$ \\
\hline $\begin{array}{l}\text { Blood pH } \\
\text { pCO } \\
\text { BE } \\
\text { SB } \\
\text { BB } \\
\text { Hematocrit } \\
\text { Hb } \\
\text { Total protein } \\
\text { Glucose } \\
\text { Urea } \\
\mathrm{Na} \\
\mathrm{K} \\
\mathrm{Ca} \\
\mathrm{Mg} \\
\mathrm{P} \\
\mathrm{Zn} \\
\mathrm{Cu}\end{array}$ & $\begin{array}{l}\mathrm{kPa} \\
\mathrm{mmol} / 1 \\
\mathrm{mmol} / \mathrm{l} \\
\mathrm{mmol} / \mathrm{l}\end{array}$ & $\begin{array}{r}7.344 \\
6.705 \\
-0.242 \\
23.648 \\
50.259 \\
0.340 \\
12.195 \\
69.423 \\
4.313 \\
5.201 \\
144.333 \\
4.916 \\
2.538 \\
1.003 \\
2.606 \\
26.799 \\
16.355\end{array}$ & $\begin{array}{r}0.061 \\
1.962 \\
3.409 \\
2.761 \\
4.231 \\
0.072 \\
1.753 \\
6.901 \\
1.286 \\
1.499 \\
3.756 \\
0.514 \\
0.222 \\
0.109 \\
0.410 \\
13.007 \\
2.391\end{array}$ \\
\hline
\end{tabular}

Table 5

Basic biochemical values of blood and blood plasma in bulls with hyperphosphataemia

\begin{tabular}{|c|c|c|c|}
\hline Parameter & Unit & $\bar{x}$ & $\mathbf{s}$ \\
\hline $\begin{array}{l}\text { Blood pH } \\
\text { pCO } \\
\text { BE } \\
\text { SB } \\
\text { BB } \\
\text { Hematocrit } \\
\text { Hb } \\
\text { Total protein } \\
\text { Glucose } \\
\text { Urea } \\
\text { Na } \\
\text { K } \\
\text { Ca } \\
\mathrm{Mg} \\
\text { P } \\
\mathrm{Zn} \\
\mathrm{Cu}\end{array}$ & $\begin{array}{l}\mathrm{kPa} \\
\mathrm{mmol} / 1 \\
\mathrm{mmol} / 1 \\
\mathrm{mmol} / 1 \\
\mathrm{~g} / \mathrm{dl} \\
\mathrm{g} / 1 \\
\mathrm{mmol} / 1 \\
\mathrm{mmol} / 1 \\
\mathrm{mmol} / 1 \\
\mathrm{mmol} / 1 \\
\mathrm{mmol} / 1 \\
\mathrm{mmol} / 1 \\
\mathrm{mmol} / 1 \\
\mu \mathrm{mol} / 1 \\
\mu \mathrm{mol} / 1\end{array}$ & $\begin{array}{r}7.357 \\
6.542 \\
0.191 \\
24.040 \\
49.406 \\
0.310 \\
11.939 \\
66.849 \\
4.377 \\
6.036 \\
145.024 \\
5.118 \\
2.626 \\
0.959 \\
3.151 \\
25.303 \\
16.384\end{array}$ & $\begin{array}{l}0.053 \\
1.554 \\
3.271 \\
2.646 \\
4.278 \\
0.068 \\
1.773 \\
8.341 \\
0.815 \\
1.388 \\
4.707 \\
0.538 \\
0.226 \\
0.130 \\
0.211 \\
9.571 \\
2.430\end{array}$ \\
\hline
\end{tabular}

Table 6

Basic biochemical values of blood and blood plasma in bulls with hypomagnesaemia

\begin{tabular}{|c|c|c|c|}
\hline Parameter & Unit & $\bar{x}$ & $\mathbf{s}$ \\
\hline $\begin{array}{l}\text { Blood pH } \\
\text { fCO } \\
\text { BE } \\
\text { SB } \\
\text { BB } \\
\text { Hematocrit } \\
\text { Hb } \\
\text { Total protein } \\
\text { Glucose } \\
\text { Urea } \\
\text { Na } \\
\text { K } \\
\text { Ca } \\
\mathrm{Mg} \\
\text { P } \\
\text { Zn } \\
\text { Cu }\end{array}$ & $\begin{array}{l}\mathrm{kPa} \\
\mathrm{mmol} / 1 \\
\mathrm{mmol} / \mathrm{l} \\
\mathrm{mmol} / \mathrm{l} \\
\mathrm{g} / \mathrm{dl} \\
\mathrm{g} / \mathrm{l} \\
\mathrm{mmol} / 1 \\
\mathrm{mmol} / 1 \\
\mathrm{mmol} / 1 \\
\mathrm{mmol} / 1 \\
\mathrm{mmol} / 1 \\
\mathrm{mmol} / 1 \\
\mathrm{mmol} / 1 \\
\mu \mathrm{mol} / 1 \\
\mu \mathrm{mol} / 1\end{array}$ & $\begin{array}{r}7.372 \\
6.353 \\
1.085 \\
24.808 \\
50.539 \\
0.293 \\
12.015 \\
69.038 \\
4.661 \\
6.228 \\
146.688 \\
4.994 \\
2.556 \\
0.733 \\
2.639 \\
30.629 \\
15.996\end{array}$ & $\begin{array}{r}0.059 \\
0.872 \\
2.770 \\
2.237 \\
4.074 \\
0.076 \\
1.514 \\
8.221 \\
0.475 \\
1.320 \\
4.715 \\
0.797 \\
0.236 \\
0.026 \\
0.376 \\
13.000 \\
2.538\end{array}$ \\
\hline
\end{tabular}


Table 7

Statistical evaluation of differences in the blood and blood plasma composition in healthy bulls and those with individual metabolic disturbances

\begin{tabular}{|c|c|c|c|c|c|}
\hline & \multicolumn{2}{|c|}{ Metabolic } & \multirow[b]{2}{*}{ Hyperphosphataemia } & \multirow{2}{*}{ Rachitis } & \multirow[b]{2}{*}{ Hypomagnesaemia } \\
\hline & acidosis & alkalosis & & & \\
\hline $\begin{array}{l}\text { Number of examined } \\
\text { animals }\end{array}$ & 80 & 18 & 168 & 96 & 26 \\
\hline $\begin{array}{l}\text { Blood pH } \\
\mathrm{pCO}_{2} \\
\mathrm{BE} \\
\mathrm{SB} \\
\mathrm{BB} \\
\mathrm{Hematocrit} \\
\mathrm{Hb} \\
\text { Total protein } \\
\text { Glucose } \\
\text { Urea } \\
\mathrm{Na} \\
\mathrm{K} \\
\mathrm{Ca} \\
\mathrm{Mg} \\
\mathrm{P} \\
\mathrm{Zn} \\
\mathrm{Cu}\end{array}$ & $\begin{array}{l}x \times \\
x \times \\
x \times \\
x \times \\
= \\
= \\
\frac{=}{x \times} \\
= \\
= \\
=\end{array}$ & $\begin{array}{l}\bar{Z} \\
x \times \\
\times x \\
\bar{x} \\
= \\
\bar{x} \\
\bar{x} \\
x \\
x \\
\bar{x} \\
x \times \\
x \times \\
x \times \\
-\end{array}$ & 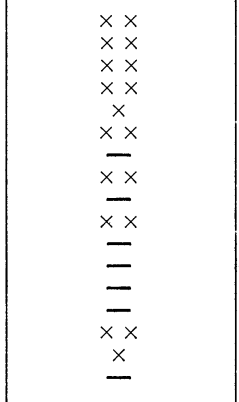 & $\begin{array}{l}x \times \\
x \times \\
x \times \\
x \times \\
= \\
= \\
= \\
= \\
\bar{x} \\
= \\
\bar{x}\end{array}$ & $\begin{array}{l} \pm \\
= \\
\bar{x} \\
= \\
\bar{x} \\
\frac{x}{=} \\
\frac{x x}{x x} \\
=\end{array}$ \\
\hline
\end{tabular}

$$
-\mathrm{p}>0.05 \quad \times \mathrm{p}<0.05 \quad \times \times \mathrm{p}<0.01
$$

Table 8

Ash content in the cancellous bone tissue of bulls (in $\mathbf{m g}$ )

\begin{tabular}{|c|c|c|c|c|}
\hline Group & & $\begin{array}{l}\text { Ash } / 1 \mathrm{~g} \text { of } \\
\text { fat-free dry } \\
\text { matter }\end{array}$ & Ash $/ 1 \mathrm{~cm}^{3}$ & $\mathrm{Ca} / \mathrm{P}$ \\
\hline $\begin{array}{l}\text { Healthy bulls daily body mass } \\
\text { gain } 0.8-1.0 \mathrm{~kg}\end{array}$ & $\begin{array}{l}\mathbf{n} \\
\bar{x} \\
\mathbf{s}\end{array}$ & $\begin{array}{c}47 \\
605.936 \\
16.393\end{array}$ & $\begin{array}{r}243.829 \\
31.463\end{array}$ & $\begin{array}{l}2.063 \\
0.072\end{array}$ \\
\hline $\begin{array}{l}\text { Subclinical rachitis daily body } \\
\text { mass gain } 0.5-0.65 \mathrm{~kg}\end{array}$ & $\begin{array}{l}\mathbf{n} \\
\bar{x} \\
\mathbf{s}\end{array}$ & $\begin{array}{r}96 \\
555.690 \\
30.944\end{array}$ & $\begin{array}{r}213.700 \\
39.621\end{array}$ & $\begin{array}{l}2.159 \\
0.148\end{array}$ \\
\hline $\begin{array}{l}\text { Subclinical rachitis and } \\
\text { osteoporosis daily body mass } \\
\text { gain } 0.5-0.65 \mathrm{~kg}\end{array}$ & $\begin{array}{l}\mathbf{n} \\
\bar{x} \\
\mathbf{s}\end{array}$ & $\begin{array}{r}44 \\
546.089 \\
30.224\end{array}$ & $\begin{array}{r}179.707 \\
25.583\end{array}$ & $\begin{array}{l}1.912 \\
0.151\end{array}$ \\
\hline $\begin{array}{l}\text { Clinical rachitis (nutrition } \\
\text { deficient in } P \text { ) }\end{array}$ & $\begin{array}{l}\mathbf{n} \\
\bar{x} \\
\mathbf{s}\end{array}$ & $\begin{array}{c}18 \\
502.111 \\
31.706\end{array}$ & $\begin{array}{r}209.650 \\
16.730\end{array}$ & $\begin{array}{l}2.172 \\
0.110\end{array}$ \\
\hline $\begin{array}{l}\text { Clinical rachitis and } \\
\text { osteoporosis (nutrition } \\
\text { deficient in } \mathrm{P}, \mathrm{Ca}, \mathrm{N} \text { ) }\end{array}$ & $\begin{array}{l}\mathbf{n} \\
\bar{x} \\
\mathbf{s}\end{array}$ & $\begin{array}{r}16 \\
491.919 \\
35.574\end{array}$ & $\begin{array}{r}173.294 \\
16.724\end{array}$ & $\begin{array}{l}1.966 \\
0.113\end{array}$ \\
\hline
\end{tabular}


phosphorus and zinc in blood plasma have been found. In hypomagnesaemic bulls the differences in hematocrit, area, magnesium and zinc have been found.

The results of bone tissue analysis are presented in Table 8. In the group of healthy bulls (47 animals) and with the growth intensity of $0.8-1.0 \mathrm{~kg}$ |animal| day an ash content in the dry matter of cancellous bone and in $1 \mathrm{~cm}^{3}$ of fresh cancellous bone was found to be $605.936 \mathrm{mg} . \mathrm{g}^{-1}$ and $243.829 \mathrm{mg}$, resp. In bulls with subclinical rachitis, significant decrease in ash content in $1 \mathbf{g}$ of fat-free dry matter has been determined. In bulls with rachitis and osteoporosis a significant fall in ash content in both $1 \mathrm{~g}$ of fat-free dry matter and volume unit has been found. The most significant changes have been observed in bulls with clinical signs of rachitis and with clinical signs of rachitis and osteoporosis.

\section{Discussion}

If the reference values of the basic hematological and biochemical parameters in blood and blood plasma of healthy bulls, presented in Table 1, are compared with those for dairy cows (Jagoš et al. 1977) the greatest difference is observed in the concentration of glucose and inorganic phosphorus in blood plasma. The content of these metabolites was found to be higher in the blood plasma of bulls. Other parameters do not differ much from those found for dairy cows and fit into the reference range. Slanina and Beseda (1979) found the reference values of hematological and biochemical parameters of dairy cows and beef cattle to be consistent. In comparison with the data presented by these authors the reference values of $\mathrm{BE}, \mathrm{Hb}$, glucose, calcium, phosphorus and copper found by us are higher and the values of hematocrit and total protein lower. If compared with the findings of Kitchenham (1977) we have observed the concentration of glucose and copper to be higher and that of phosphorus lower. The urea content in bulls on a diet of maize silage and on pressed feeds was found to be higher and lower, resp. than reported by Kitchenham (1977).

According to this author the level of natraemia was lower and that of kalaemia higher. If we compare the reference values of minerals in the blood plasma of bulls with our previous results no significant differences are evident. The only difference was observed in inorganic phosphorus. For bulls of $200-250$ and $450-650 \mathrm{~kg}$ body mass ranges we presented a reference value of $2.82 \pm 0.11 \mu \mathrm{mol} / 1$ and $2.01 \pm 0.25$ $\mu \mathrm{mol} / 1$, resp. (Jag oš et al. 1975).

The reference values found in the present experiment lie approximately in the middle. They are identical or very similar to those given by Kroupová (1971) for bulls on a maize diet.

It follows that the determination of the so-called reference values in fattening bulls is not simple and that the age of animals, their growth rate and the system of feeding have to be taken into account. An objective comparison of the found values with those of other authors is very complicated since the latter include the examination of a small number of animals of various breeds or the number of animals is not stated at all. Rowlands and Manston (1976) state that the use of chemical analysis of blood in order to follow the health condition and the nutrition level of fattening cattle requires the comparison of the results with the reference values measured in animals with known optimal growth rate in the given system of fattening.

When determining the reference values the warning of Kitchenham and Rowlands (1976) should be taken into consideration. These authors pointed out that the chemical composition of blood of cattle is liable to the genetic control. Rowlands and Manston (1976) presume that the hemoglobin, potassium and copper 
concentrations in blood are subject to genetic control. Rowlands et al. (1974) have shown a direct correlation between the growth rate and the glucose, albumin, hemoglobin and potassium concentrations. Similarly, Kitchenham (1976) has found a higher growth rate in young cattle with a higher content of albumin in the blood plasma.

Owing to a considerable cross-breeding of our cattle, unsatisfactory health situation, and to imbalanced nutrition of animals in the investigated farms the levels of individual parameters, growth rate and the type of technology could not be objectively evaluated from the point of view of genetic origin. For this reason the reference values in this stage of research were determined for fattening bulls weighing $320-400 \mathrm{~kg}$, with the growth rate of $0.8-1.24 \mathrm{~kg} /$ animal/day, the feed ration being based on maize silage.

The values of basic hematological and biochemical parameters in blood and blood plasma of bulls suffering from metabolic acidosis, metabolic alkalosis, hyperphosphataemia, rachitis and hypomagnesaemia are presented in Tables $2-6$. The significance of differences compared with reference values is given in Table 7 .

The values of acid-base balance $\left(\mathrm{pH}, \mathrm{pCO}_{2}, \mathrm{BE}, \mathrm{SB}\right.$ and $\left.\mathrm{BB}\right)$ in the case of metabolic acidosis were found to be statistically highly significant as compared to the reference values, the only exception being $\mathrm{pCO}_{2}$. Also the concentration of inorganic phosphorus in the blood plasma was highly significant. Other biochemical and hematological parameters followed did not differ from the reference values.

In bulls with the occurrence of metabolic alkalosis significantly changed values of $\mathrm{BE}$ and $\mathrm{SB}$ have been observed, $\mathrm{pH}$ was only slightly increased, the difference being not statistically singificant. Alkalosis was found to be moderate and often fully compensated.

Further significant changes were observed in the hematocrit, $\mathrm{Mg}, \mathrm{P}$ and $\mathrm{Zn}$ content. The concentrations of hematocrit, $\mathrm{Mg}$ and $\mathrm{K}$ were found to be lower, those of inorganic phosphorus, $\mathrm{Na}, \mathrm{Zn}$ and urea being, however, significantly higher. The changes in $\mathrm{Na}$ and $\mathrm{K}$ content in the blood plasma in metabolic alkalosis are given by the level of ion exchange between intracellular and extracellular fluid. In metabolic acidosis the transfer of $\mathrm{K}$ from cells to ECT and of $\mathrm{N}$ from ECT to cells occurs, this process being opposite in the case of metabolic alkalosis (Siggaard-Andersen 1962; Kildeberg 1968; Wright 1970; Jagoš et al. 1975). Svendsen (1969) observed a decrease of $2 \mathrm{mmol} / 1$ in the $\mathrm{K}$ concentration in the blood plasma of animals with the experimentally induced metabolic alkalosis.

In our experiment the $\mathrm{K}$ content in the blood plasma of bulls with metabolic alkalosis was lower only by $0.39 \mathrm{mmol} / 1$, that of $\mathrm{Na}$ being, on the other hand, by 3.34 $\mathrm{mmol} / 1$ higher. With regard to the changes of $\mathrm{Na}$ and $\mathrm{K}$ content in extracellular fluid the changes in the volume of internal environment can also be expected.

$\mathrm{Na}^{+}$has a considerably higher hydration level than $\mathrm{K}^{+}$. The $\mathrm{Na}^{+}$hydration is given by the bonding of 4.3 molecules of water, that of $\mathrm{K}^{+}$only by 0.9 molecule of water (Hořejší 1970).

The changes in $\mathrm{Na}$ and $\mathrm{K}$ content in acid-base status disturbances are accompanied by water transfer between intra and extracellular fluid (Cort and Fencl 1957; Fayet 1971). The statistically significant decrease of hematocrit concentration and an indication of the decrease in plasma proteins could be, to a certain extent, explained by the increase of ECT volume.

The main etiologic factor of metabolic alkalosis in bulls was found to be due to overfeeding with nitrogen compounds. Excessive intake of digestible nitrogen compounds in the feed ration caused hyperuremia, induced alkalic condition already 
in forestomachs and limited $\mathrm{Mg}$ absorption, thus decreasing significantly the $\mathrm{Mg}$ content in the blood plasma.

So far we have not been able to elucidate a highly significant increase of plasma $\mathrm{Zn}$ in the blood plasma in cases of metabolic alkalosis.

Metabolic acidosis and a significant fall in the total protein and hematocrit content and hyperuremia were found very frequently in cases of hyperphosphataemia.

Whether the metabolic acidosis was of primary or secondary origin is difficult to decide unambiguously.

The significant increase of urea in the blood plasma could be caused, apart from the excessive intake of digestible nitrogen compounds, by the increased catabolism or by kidney disturbances (Slanina 1979). Hypoproteinaemia corroborates the theory of lowered proteosynthesis and defective utilization of digestible nitrogen compounds.

Significantly changed values of acid-base balance, $\mathrm{K}$ and $\mathrm{Zn}$ concentrations in the blood plasma and the ash content in the bone tissue were observed in bulls with rachitis. In our experiment statistically significant changes in the average content of inorganic $\mathrm{P}, \mathrm{Ca}$ and $\mathrm{Mg}$ in the blood plasma of bulls with subclinical rachitis were found. We have, however, observed both lowered and increased values of inorganic $P$ in the blood plasma, the standard deviation of the inorganic $P$ content in the blood plasma in comparison with healthy bulls being twofold.

It could be concluded from the presented results that the content of osteotrophic minerals in the blood plasma cannot provide an objective picture of the level of bone tissue mineralization and on the change of cartilage to bone tissue. That is the reason why subclinical rachitis in cattle cannot be diagnosed on the basis of $\mathrm{Ca}$ and $\mathrm{P}$ content in the blood plasma.

The decisive role in the diagnosis of subclinical rachitis belongs to the examination of bone tissue (ash content in $1 \mathrm{~cm}^{3}$ and in $1 \mathrm{~g}$ of dry and fat-free bone tissue). This examination, completed by histological and histochemical results, is decisive for diagnosis and differential diagnosis of osteopathies (Priboth 1966; Priboth and Fritzsche 1969; Jagoš et al. 1975).

In bulls with subclinical hypomagnesaemia, which was diagnosed in $2.53 \%$ of the animals examined, statistically significant differences in the $\mathrm{Mg}$, hematocrit, urea, $\mathrm{Zn}$ and $\mathrm{Na}$ concentrations have been found. The average $\mathrm{Mg}$ content in the blood plasma was found to be $0.73 \pm 0.02 \mathrm{mmol} / 1$, this being by $0.25 \mathrm{mmol} / 1$ less when compared with healthy animals. This value is pathognomonic for subclinical tetanies in cattle generally (J agoš et al. 1975), being found also in individual animals with the clinical syndrome of hypomagnesaemia (Ja goš et al. 1974).

Predominantly the $\mathrm{Mg}$ deficiency in the feed ration and the incomplete absorption of $\mathrm{Mg}$ due to the excess of digestible nitrogen compounds and $\mathrm{K}$ in the feed ration, the lack of crude fiber, overfeeding with $\mathrm{Ca}, \mathrm{P}$, alkalosis of the rumen content and inflammation processes of the digestive system could all be regarded as causing agents for the hypomagnesaemia development (Rosenberger 1970; Payne 1970, 1972; Gürtler 1972, 1973; Jagoš et al. 1974). In our investigation the increased content of digestible nitrogen substances in the feed ration and an excess of $\mathrm{K}$ were observed to participate predominantly in the occurrence of hypomagnesaemia. These deficiencies were found in the fattening centres, where apart from maize silage, also poultry litter and urea were fed. The increased urea content in the blood plasma confirmed the overfeeding of animals with nitrogen substances. Neither in this experiment nor in our previous investigation have we found sinultaneous $\mathrm{Ca}$ and $\mathrm{P}$ decrease in the blood plasma of hypomagnesaemic animals. The increased concentration of $\mathrm{Zn}$ in the blood plasma is due to the higher intake of $\mathrm{Zn}$ in the feed ration supple- 
mented by poultry litter containing $80-150 \mathrm{mg}$ of $\mathrm{Zn} / \mathrm{kg}$ of dry matter, this being in accordance with the observation made by Illek (1979). This author has proved that the $\mathrm{Zn}$ content in the blood plasma reflects directly the $\mathrm{Zn}$ concentration in the feed ration.

The significant decrease in the hematocrit of bulls with hypomagnesaemia cannot be unequivocally explained. The extent of the participation of $\mathrm{Mg}$ deficiency in this syndrome has not yet been determined. It is, however, probable that the cause of the lowered hematocrit value is multifactorial, hypomagnesaemia being not the only causing factor. The fall in hematocrit values has been observed also in metabolic alkalosis and hyperphosphataemia, i.e. in metabolic disturbances reflecting imbalanced feed rations and digestive disorders in forestomachs.

\section{Metabolický profil býků v žíru v podmínkách velkovýrobních technologií}

V 10 specializovaných závodech pro výkrm skotu byl sledován pomocí systému preventivní diagnostiky vývoj zdravotního stavu zvírat. Byl stanoven metabolický profil u býků zdravých, u býků s poruchami typu metabolické acidózy, metabolické alkalózy, rachitidy, hyperfosforémie a hypomagneziémie. Byly prokázány statisticky významné rozdíly $\mathrm{v}$ hodnotách základních biochemických ukazatelů mezi skupinou zvírat zdravých a skupinami postiženými jednotlivými metabolickými porụchami. Jsou diskutovány přičiny a charakter změn $\mathrm{v}$ biochemickém profilu jednotlivých skupin zvírat a možnost využití získaných poznatků $\mathrm{v}$ časné diagnostice metabolických poruch u býků v žíru.

\section{Метаболический профиль быков в выкормке в условиях крупнопроизводственных технологий}

На десяти специализированных заводах по откорму крупного рогатого скота с помощью системы профилактической диагностики проводились исследования состояния здоровья животных. Был определен метаболический профиль у здоровых быков, у быков с нарушениями типа метаболического ацидоза, метаболического алкалоза, рахита, гиперфосфоремии и гипомагнезиемии. Была установлена статистически значимая разница величин основных биохимических показателей между группой здоровых животных и животных, страдающих отдельными метаболическими нарушениями. Обсуждаются причины и характер изменений биохимического профиля отдельных групп животных и возможности использования полученных знаний в своевременно поставленном диагнозе метаболических нарушений у быков в выкормке.

\section{References}

CORT, J. H. - FENCL, V.: Tělesné tekutiny. Praha, SZN, 1957, 355 p.

FAYET, J. C.: Plasma and faecal osmolality, water kinetics and body fluid compartments in neonatal calves with diarrhoea. Brit. Vet. J., 127, 1971: 37-44.

GÜRTLER, H. - STEPHAN, V. - GRUN, E.: Untersuchungen zum Vorkommen zur Pathogenese und zur Prophylaxe der Weidetetanie des Rindes. Mh. vet. Med., 27, 1971: 891-899. GÚRTLER, H. - STEPHAN, V. - FEIST, H.: Untersuchungen zum Vorkommen zur Patho- 
genese und der Prophylaxe der Weidetetanie des Rindes. 4. Mitt.: Zum Einsatz von Magnesium-Staben zur Prophylaxe der Weidetetanie. Mh. vet. Med., 28, 1973: 287-200.

HOMOLKA, J.: Klinické biochemické vyšetřovací metody. Praha, SZN, 1971, 440 p.

HOKEJŜ́, J.: Základy klinické biochemie ve vnitřním lékařství. Praha, Avicenum, 1970, 548 p.

ILLEK, J.: Diagnostika karencí manganu, mědi a zinku u dojnic. PhD Thesis, University of Veterinary Science, Brno, 1979, 182 p.

JAGOŚ, P. - BOUDA, J. - ILLEK, J. - HOFÍREK, B.: Rozpracování metabolických testů $\mathrm{k}$ určení skrytých poruch výměny látkové $\mathrm{u}$ dojnic $\mathrm{v}$ podmínkách průmyslových komplexủ. Project report, University of Veterinary Science, Brno, 1975, $50 \mathrm{p}$.

JAGOS, P. - ILLEK, J. - BOUDA, J. - DVOKAK, R. - TLUCHOR, V.: Vypracování systému preventivní diagnostiky poruch výměny látkové u skotu. Project report, University of Veterinary Science, Brno, 1980, 35 p.

JAGOS, P. - ILLEK, J. - JURAJDOVA, J. - HAMŚfK, Vl.: Poruchy metabolismu mikroprvků u skotu. Předneseno na 13. vědecké konferenci o aktuálních otázkách ochrany a kontroly zdravia hosp. zvierat v intenzívnej živočišnej výrobe, Košice, 1974.

JAGOŚ, P. - ILLEK, J. - JURAJDOVÁ, J. - HAMŚ́́K, V. - BOUDA, J.: Průzkum a vyhodnocení zdraví a veterinární prevence ve vybraných výkrmnách skotu. Project report, Brno, $1975,58 \mathrm{p}$.

JAGOS, P. - ILLEK, J. - BOUDA, J. - DVORAK, R. - HOFÍREK, B. - LEBEDA, M. MACHÝČKK, V. - ZÝKA, V. - ZIMA, L.: Metodika provádění a interpretace metabolického testu u skotu. Ústav vet. osvěty SVS Pardubice, 1977, 33 p.

JAGOS, P. - ILLEK, J. KONVALINOVA, D. - VALACH, Z. - JURAJDOVA, J. DOUBEK, J. - CERNÁ, E. - ONDROVÁ, J. - STŔ́Ž, J.: Studium poruch minerálního metabolismu u ovcí. Project report, Brno, 1980, 71 p.

JAGOS, P. - ILLEK, J. - ZÝKA, V.: Systém preventivní diagnostiky metabolických a produkčních poruch $\mathrm{v}$ chovech prasnic. Veterinární péče ve velkochovech prasat. Ústav vet. osvěty SVS Pardubice, 1981, 26 p.

KILDEBERG, P.: Clinical acid-base physiology. Studies in neonates, infants and young children. Munkagaard, 1968, $228 \mathrm{p}$.

KITCHENHAM, B. A. - ROWLANDS, G. J.: Differences in the concentrations of certain blood constituents among cows in a dairy herd. J. agric. Sci., Camb., 86, 1976: 171-179.

KITCHENHAM, B. A. - ROWLANDS, C. J. - MANSTON, R. - BALDRY, A. F.: Individuality and relationships with growth rate observed in the concentrations of certain blood constituents of bulls and steers reared on three systems of beef production. Br. vet. J., 133, $1977 ; 175-182$.

KROUPOVA, V.: Biochemický a morfologický krevní obraz býčků krmených kukuřičnou monodietou ve vztahu $\mathrm{k}$ jejich rủstové intenzitě. In: Monodietní výživa skotu $\mathrm{z}$ hlediska veterinární péče. ČSVTS Ústí n. Labem, 1971: 64-89.

PAYNE, J. M.: Production disease in ruminants under conditions of modern intensive agriculture. Inter. Rev. Exp. Pathol., 9, 1970: 191-232.

PAYNE, J. M.: Metabolic Diseases in Farm Animals. W. H. Medical Books Ltd, London, 1977, $206 \mathrm{p}$.

PRIBOTH, W.: Experimentelle und klinische Untersuchungen zur Diagnostik und Frühdiagnostik der mineralmangelbedingten Osteopathien der Jungrindern. Habil. Schrift, Leipzig, KarlMarx-Univ., 1966, 196 p.

ROSENBERGER, G.: Krankheiten des Rindes. Verl. Paul Parey, Berlin-Hamburg, 1970, $1390 \mathrm{p}$.

PRIBOTH, W. - FRITSCHE, H.: Experimentelle und klinische Untersuchungen uber Störungen der Ca-P-Stoffwechselregulation bei den Osteopathien des Rindes. I. Mitt.: Die Wirkung einer Phosphormangelfütterung auf das Skelett des Jungrindes. Chemische und physikalische Untersuchungen an postmortem entnommenen Knochenmaterial als Grundlage für die Entwicklung bioptischchemischer und röntgenologisch-photometrischer Verfahren. Arch. exp. Vet. Med., 23, 1969: 653-673.

ROWLANDS, G. J. - MANSTON, R.: The potential use of metabolic profiles in the management and selection of cattle for milk and beef production. Livestock Prod. Science, 3, 1976: $239-256$.

ROWLANDS, G. J. - PAYNE, J. M. - DEW, S. M. - MANSTON, R.: Individuality and heritability of the blood composition of calves with particular reference to the selection of stock with improved growth potential. J. Agr. Sci., Cambridge, 82, 1974 b: 473-481.

SIGGAARD-ANDERSEN, O.: Acute experimental acid-base disturbances in dogs. An investigation of the acid-base and electrolyte contents of blood and urine. Scand. J. clin. Lab. Invest., 14, suppl. 66, 1962b: $1-2$.

SIGGARD-ANDERSEN, O.: The acid-base status of the blood. Scand. J. clin. Lab. Invest., 15, 1963: 134. 
SLANINA, L.: Neadekvátna úžitkovosṫ hovädzieho dobytka vo velkovýrobných podmienkach. Veterinářství, 23, 1973: 202-203.

SLANINA, L. - BESEDA, J.: Metabolický profil hovädzieho dobytka vo vztahu $k$ zdraviu a úžitkovosti. Ústav vet. osvety SVS SSR Bratislava.

SVENDSEN, P.: Evidence of a potassium shift from the extracellular to the intracellular fluid space during metabolic alkalosis in cattle. Nord. Vet-Med., 21, 1969: 660-663.

WRIGHT, S.: Klinická fyziologie, Praha, Avicenum, 1970; 679 p. 